\title{
Soil Quality Indices- Special Focus on Salt-Affected Soil: Review and Case Study in Northern Egypt
}

\author{
Heba Elbasiouny ${ }^{1}$; F. Elbehiry ${ }^{2^{*}}$ and M. Abowaly ${ }^{3}$ \\ ${ }^{1}$ Biological and Environmental Sciences Department, Faculty of Home Economic, \\ Al-Azhar University, 31511, Egypt ${ }^{2}$ Central Laboratory for Environmental Studies \\ and ${ }^{3}$ Department of Soil and Water Sciences, Faculty of Agriculture, Kafrelsheikh, \\ University 33516, Egypt.
}

\begin{abstract}
SOIL plays an important role in human health and environmental quality.Therefore, there

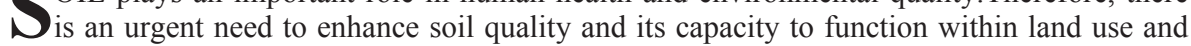
ecosystem boundaries.Measuring the change in soil properties is important and critical for monitoring change in soil quality. Although the concept of soil quality is clear, there is a little consensus about its measurement because multiple functions of soil and interaction between its properties. Soil quality can be measured by using soil properties as indicators or measurable alternative about soil performance in relation to specific function(s). The integration between soil properties through establishing minimum data sets (MDS) is required to identify an appropriate method to assess soil quality. The MDS is specific to each soil type and functions. For example, MDS for soils in arid and semi-arid regions should include salinity as indictor, but notfor those in the humid regions. The synthesis of soil quality indicators into appropriate index is essential to assess the soil status and choosean appropriate method for enhancing soil quality. Salt-affected soils in arid and semi-arid regions have been degraded and have low economic yields. Salt-affected soils occurin about 75 countries, and occupy at least $20 \%$ of the irrigated lands in the world. Therefore, it is necessary to establish MDS to assess and enhance the quality of these soils because the restoration of these soils not only leads to increasein productivity and improvement in environmental quality but also to soil carbonsequestration.
\end{abstract}

Keywords: Soil Quality, Salt-affected soils, Minimum data sets, Egypt.

\section{Introduction}

Soil is a living system, and is a finite but vital resource to life on earth.It provides an appropriate environment for agricultural production, and it is also critical for improving environmental quality (e.g. source/sink for greenhouse gases, recycling nutrients, filtering and purifying water and pollution, etc). It is comprised of a thin surface layer of complex mixtures of minerals and soil organic matter (SOM). It is developed slowly from different parent materials impacted upon soil forming factors (i.e. time, climate, organisms, and topography). Soil components interact together in response to biological, chemical and physical forces. In addition, soil affects and is affected by land use (Dumanski, 1997; Asadi et al., 2008; Zhengchao, 2015). Hence the successful management and enhancement of soil quality are integrative indicatorsof sustainable agriculture, maintaining or enhancing the environmental quality and conserving natural resources (Herrick, 2000).

Because a soil has complex and multiple functions, it is appropriate that soil quality is understood in the context of its capacity to perform specific function. Therefore, soil quality is not measured directly but inferred from measurable and specific indicators. Thus, there is a need to identify proper soil quality indicators that respond to changes in management systems; reflect an accurate response to deterioration and soil functioning; and integrate soil physical, chemical and/or biological properties and processes that can be applied under diverse field conditions. Based on this, soil scientists have identified minimum data sets (MDSs) that consist of relevant soil parameters (Wander and Bollero, 1999; Sant'anna,

\footnotetext{
*Corresponding author: Dr. Fathy Elbehiry

Email: Fathyelbehiry@gmail.com -Fathy.Bhriri_0533@agr.kfs.edu.eg

Telephone:+201024208938

DOI : $10.21608 /$ jenvbs.2017.1085.1005

C2017 National Information and Documentaion Center (NIDOC)
} 
2001; Norfleet et al., 2003; Shukla et al., 2006), which differ among soil functions. Soil quality indicatorsshould be integrated into a soil quality index. However, an important current challenge for soil scientists is to construct an accurate and sensitive index for assessing soil quality, because of variations in soil conditions depending on the particular priorities and conditions (Zornoza et al., 2008). Thus, a soil quality index should integrate physical, chemical, and biological properties of the soil in any conditions (such as salinization in arid and semi-arid regions) to be a good guide for the state of soil and its functioning. This enables land managers to maintain or enhance the quality of the soil and surrounding ecosystem; and hence sustainability.

Therefore, there is a need to monitor and enhance soil quality, especially in salt-affected soils, which upon reclamation can increase the productivity and sustainability (Qadir et al., 2006). Furthermore, the restoration of saltaffected soils may lead to enhanced carbon (C) sequestration and environmental quality (Qadir et al., 2006). Then, the objectives of this article are to: i) identify appropriate indicators to establish MDS for assessing quality of salt-affected soils; ii) identifythreshold valuesof indicators related to salt-affected soils and iii) asses soil quality in some soils in Egypt as semi-arid region.

\section{Soil functions and quality}

Historically, assessment of soil quality meant land evaluation. This concept has changed as a result of current interests in soils for their fitness to specific use, and performance specific function (Lal et al., 1997; Braimoh and Vlek, 2008). Recently, soil quality is defined as "a capacity of a soil to function within land use and ecosystem boundaries, to sustain biological productivity, to maintain environmental quality and to promote plant, animal and human health". It is focused on the productive functions of soils, and recognizes the various roles that soils play in agroecosystems and natural systems" (Karlen et al., 1997; Zalidis et al., 2002; Norfleet et al., 2003; Sanchez et al., 2003; Shukla et al., 2004;Braimoh and Vlek, 2008; Seker et al., 2017).

There are five primary functions of soil: (1) sustaining biological activity, diversity, and productivity;(2) regulating water flow, filtering, buffering, degrading, immobilizing, and detoxifying organic and inorganic materials, including industrial and municipal by-products and atmospheric deposition;(3) storing and cycling nutrientsand other elements within the biosphere; (4) providing support for socioeconomic structures; and (5) protection of archeological treasures associated with human habitation (USDA, 1999; Zalidis et al., 2002; Norfleet et al., 2003; Tóth et al., 2007). Then, soil quality should be assessed in the context of specific function(s) to appropriate properties that support this function(s).

Although the concept of soil quality seems to be clear, and is supported by a broad consensus, there is a little agreement and no systematic procedure or universal standards for identifying soil properties or parameters that should be included in soil quality assessment. (Sa'nchezMarano'n, et al 2002; Sposito and Zabel, 2003; Wang, 2003; Zornoza et al., 2007). This is the case in most soils because most authors dealt with the assessment of soil quality from general point of view and didn't discuss specific conditions such as salinization. Thus, there is a reason to address such topic in these soils especially under the global food shortage and environmental issues such as climate change to enhance the capacity of these soilsto produce and sequester more carbon.

Thus, soil quality cannot be measured directly, but is based on determining the critical soil properties (indicators) that refer to the status of physical, chemical, and biological soil attributes and reflect its performance and functioningin addition to agroecosystem services (Andrews and Carroll, 2001; Moebius et al., 2007; Schindelbeck et al., 2008; Zvomuya., et al 2008). In this context; there are some parameters that should be taken into consideration when selecting soil quality indicators, such as its relation to use and management; relevance and ability to measure the change in the important soil functions; ease and cost of sampling; ease and reliability of measurement; comparability with routine sampling and monitoring programs; assessment in a reasonable amount of time; cost of analysis; accessibility to many users and applicable to field conditions; spatial and temporal variations in the soil system; and sensitivity to variations in climate and management (USDA, 2001; Nortcliff, 2002; Lee et al., 2006; Raman, 2006; Schindelbeck et al., 2008).In addition to selecting appropriate indicators, there is a need to establish standard or reference (baseline, threshold, or critical) values 
for these indicators. These values are specific limits or ranges for an indicator in a particular soil or group of similar soils (Raman, 2006). The selected indicators should be incorporated and integrated into (MDS) to integrate and interface between soil function(s) and soil properties or processes. Then this helps to deduce the performance of soil for its essential function(s) and achieve intended target from the assessment (Halvorson et al., 1996; Lee et al., 2006; Sant'anna et al., 2001).Although, there are some proposed MDSs (i.e. Wander and Drinkwater, 2000; USDA, 2001; Arshad and Martin, 2002 Baldwin, 2006), additional MDS should be established based on soil type, its functions and related conditions. For example, MDS for soils of humid regions would not probably include salinity as an indicator which is important for those in the arid and semi-arid regions. However, there are proposed MDS which include the basic set of soil properties which can measure or characterize soil quality (Wander and Drinkwater, 2000; USDA, 2001; Arshad and Martin, 2002; Andrews et al., 2004; Shukla et al., 2004; Raman, 2006). Hence, indicators included in MDS should be integrated into specific index that represent the soil quality aspect or direction (Andrews et al., 2004). To date there are no magic indices or scores for soil properties. However, there are some suggested valuable indices such as those proposed by Doran and Parkin, 1994; Karlen and Stott, 1994; Larson and Pierce, 1994; Glover et al., 2000; Arshad and Martin; 2002; Andrews et al., 2003; Andrews et al., 2004; Lee et al., 2006; Tóth et al., 2007; Asadi et al., 2008.Knowning the advantages or disadvantages of these indices, the changes in soil quality, negatively or positively, can be assessed.

\section{Negative changes in soil quality}

Soil quality indices reflect the status of soil properties and its performance of the function(s). These values are generally high in native soils which are developed under climax vegetation in equilibrium with the environment and without any anthropogenic disturbance. Thus, the maintenance of this equilibrium is related to increasing the soil quality or at least keeping soil quality at the same level without any negative changes (Leirós, et al., 1999).

Several reasons of negative changes in grouped into two broad categories: (i) inadmissible concentrations of contaminants; and (ii) restrictions on soil function as a result of different types of soil degradation, such as contamination, loss of SOM, acidification, salinization, compaction, wind erosion, water erosion, deterioration of physical properties and other processes that lead to reduction in soil quality (Cassman, 1999; Nortcliff, 2002; Shukla et al., 2004).Salt-affected soils are among important degraded ecosystems which must be reclaimed for increasing productivity and sustainability. Based on Lakhdar et al., (2010) excessive amounts of salt then salt toxicity is one of the major edaphic factors that limit the production and environmental quality in these soils. The salt toxicity can adversely influence on physical, chemical and biological properties and processes in the soil. Therefore, there is a need to discuss salt-affected soils form the qualityprescriptive.

\section{Quality of salt-affected soils}

Before discussing the quality of saltaffected soils, the highlight should be directed to salinization and the general properties to saltaffected soils. Salinization is the most common and among serious soil degradation processesin arid and semi-arid climates because the evaporation> precipitationin these regions (Eynard et al., 2005; Abdelfattah et al, 2009).Salt-affected soils also occur in other regions,climates and soil types (Mashali 1999;Eynard et al., 2005; Rengasamy, 2010). Cilenti et al. (2005) stated that salinization is one of the greatest concern desertification processes in the Mediterranean area.

\section{Major factors influencing soil salinization}

The factors influencing salinization are set in two wide groups; natural and human induced factors. Natural factors are represented in climate, soil parent material, land cover, topography, in addition to soil attributes. On the other hand, human induced factors result in what so-called secondary salinization. These factors are summarized in land use and management and land degradation. The last factors can lead to salinization or sodification through irrigation by saline or waste water, rising water table resulting from improper irrigation and drainage, intensive agriculture especially with using fertilizers and amendments under limited potentiality of leaching in addition to soil contamination with industrial by-products (Tóth et al., 2008).

Hence in addition to climatic conditions, effects of salinization and sodification are more 
drastic in soils prone to secondary salinization due to poor irrigation and improper drainage management (Rietz and Haynes, 2003; Li et al., 2007). Secondary salinization can accelerate land degradation by excessive salt concentration which leads to dispersion, surface sealing and crust formation and structural changes. Furthermore, salinization decreases crop yield through toxic effectsof some salts and high osmotic pressure whichreduces water availability as well through high salt content in the soil solution (Oostrum, 2004; Farifteh et al., 2007).

Salt-affected soils occur in as many as 75 countries, and also impact on $20 \%$ of the irrigated lands in the world. Land area affected by salinization is as high as $30 \%$ or more in countries such as Egypt, Iran and Argentina (Qadir et al., 2006; Abdelfattah et al, 2009). Salt-affected soils occupy approximately $955 \mathrm{Mg}$ ha in the world, $10 \%$ of total surface of dry lands (Li et al., 2007). Therefore, there is an urgent need to monitor and identify salt-affected soils, and assess the extent and severity of degradation for obtaining acceptable estimates of available resources for sustainable soil uses and management (Mashali, 1999; Abdelfattah et al, 2009; Farifteh, 2007; Farifteh, 2008). The sustainable use of these soils can produce more food and feed, and also enhance soil carbon sequestration (Qadir et al., 2006; Lal, 2004; 2008). Then, assessing and enhancing quality of salt-affected soils can be recognized by establishing MDS in relation to soil quality.

\section{Soil parameters related to salinity}

Important parameters related to soil salinity include: total dissolved solids (TDS) in milligram per liter, and total concentration of soluble cations (TSC) and anions (TSA) in milliequivalents per liter $/ \mathrm{kg}$. Total salt content can be measured by the electric conductivity of saturated soil extract (ECe), but individual cations in these extracts are usually determined by flame atomic absorption and flame emission spectrometry. ECe is the most common indicator for soil salinity, and its unit is decisiemens per meter $(\mathrm{dS} / \mathrm{m})$ (Farifteh et al., 2008). SoilpH is also an important parameter because of its role in plant nutrients availability. Major soluble cations $\left(\mathrm{Na}^{+}, \mathrm{Ca}^{2+}\right.$, and $\left.\mathrm{Mg}^{2+}\right)$ are important parameter to identify the nature of these soils by using index such as Sodium Adsorption Ration (SAR), while $\mathrm{Na}^{+}$exchangeable are important to identify Exchangeable Sodium Percentage (ESP) (United States Salinity

Env. Biodiv. Soil Security Vol.1 (2017)
Laboratory Staff, 1954; El-Swaif, 2000; Oostrum, 2004):

$$
\mathrm{SAR}=\left(\mathrm{Na}^{+} /\left(\mathrm{Ca}^{2+}+\mathrm{Mg}^{2+}\right)\right)^{1 / 2} \text {........Eq. } 1
$$

Where $\left(\mathrm{Na}^{+}, \mathrm{Ca}^{2+}\right.$, and $\left.\mathrm{Mg}^{2+}\right)$ are expressed as $\mathrm{mmol} / \mathrm{L}$.

$$
\mathrm{ESP}=(\mathrm{Na} \text { excha/CEC }) \times 100 \text {........Eq. } 2
$$

Where $\mathrm{Na}$ excha is exchangeable $\mathrm{Na}$ and $\mathrm{CEC}$ is Cation Exchange Capacity, both expressed as mmolc/kg (Rengasamy, 2010). The higher the SAR in soil, the higher isthe exchangeable $\mathrm{Na}+$ and the higher is thelikelihood of low soil permeability (Oostrum, 2004).

Based on the pervious soil parameters and their values salt-affected soils are classified into three categories: saline, sodic, and saline-sodic (Wong et al., 2004; and Horneck et al., 2007).

Physical and chemical characteristics of saltaffected soils categories

1.Saline soils are characterized by high concentrations of salts such as $(\mathrm{Na}+, \mathrm{K}+, \mathrm{Ca} 2+$, $\mathrm{Mg} 2+, \mathrm{Cl}-, \mathrm{SO} 4--, \mathrm{CO} 3---$, and $\mathrm{HCO} 3$ ), but the predominant salts are $\mathrm{Ca} 2+$ and $\mathrm{Mg} 2+$. High salts concentrations increaseelectric conductivity (EC) to $>4 \mathrm{dS} / \mathrm{m}$. The concentration 4 (as measured from soil paste extract) is established as the dividing line betweensalinity and non-salinity in soils. Furthermore, some saline soils are waterlogged. Most salts in soil solution (i.e. Ca2+ and $\mathrm{Mg} 2+$ ) improve soil structure and increase water infiltration. However, high salinity may lead to white crust formation on the soil surface. In addition, salinity effects on soil/water and plant/water relationships, and the high level of salts in soil cause osmotic stress to plants, leading to reduce growth plants and productivity (Bohn et al., 2001; McCauley and Jones, 2005; Marcum, 2006; Wong et al., 2006; Horneck et al., 2007).

2.Sodic soils have a high level of exchangeable $\mathrm{Na}+$ which is the dominant cation on the exchange complex. The dispersed clay and silt particles are washed into pores, and reduce air permeability and water infiltration. Usually $\mathrm{pH}$ in these soils is $>8.5$ as a result of hydrolysis of $\mathrm{Na} 2 \mathrm{CO} 3$ or exchangeable $\mathrm{Na}+$. In addition, these soils are characterized by slaking and dispersion on wetting and massive hardsetting on drying. But the most common characteristic of sodic soils is the dispersion which influences water and air movement; available water holding capacity and restricted root penetration (Oostrum, 2004; Qadir et al., 2006; Wong et al., 2006; Horneck et al., 2007). 
3. Saline-sodic soils are characterized by high soluble salts and high exchangeable $\mathrm{Na}+$ (Bohn et al., 2001), but have a good soil structure and adequate movement for water and air (Horneck et al., 2007). The $\mathrm{pH}$ of these soils is less than $8.5 \%$ because the soluble salts prevent hydrolysis. The main problem in these soils is occurred as a result of leaching, because of removing the salts faster than $\mathrm{Na}$ resulting conversion to sodic soils (Bohn et al., 2001). The most common characteristics of salt-affected soil are represented in Table 1. Such description of salt-affected soils is useful in determining indicators to be incorporated in the MDS for assessing and enhancing quality.

TABLE 1. Salt-affected soils categories and its characteristics.

\begin{tabular}{llllll}
\hline Category & $\mathbf{E C ~} \mathbf{d S} / \mathbf{m})$ & SAR & ESP & pH & Structure \\
\hline $\begin{array}{l}\text { None saline }- \text { none } \\
\text { sodic }\end{array}$ & $<4$ & $<13$ & $<15$ & $<8.5$ & good \\
Saline & $>4$ & $<13$ & $<15$ & $<8.5$ & good \\
Sodic & $<4$ & $>13$ & $>15$ & $>8.5$ & poor \\
Saline-sodic & $>4$ & $>13$ & $>15$ & $>8.5$ & fair to good \\
\hline
\end{tabular}

Establishing MDS and threshold values for indicators to assessquality of salt-affected soils

Since soil salinity is one of the major destructive degradation processes to the quality of soil as a result of damaging one or more of its functions. (Tóth et al., 2008), MDS that required toassessing the quality in salt-affected soils should be established based on the related properties. As well relationship between indicators and soil function (i.e. more is better, less is better, or optimum is better), in addition to thresholds values based on soil properties are considered to obtaining best assessment. Then, the higher accurate selecting MDS based on the soil and climate conditions, the higher accurate assessment of soil quality and the better management of these soils.

Table 2 (a-b-c) outlines the proposed MDS to assess the quality of thesesoils. It also outlines the relationship between indicator and soil function(s) according to (Glover et al., 2000; Andrews et al., 2003; Andrews et al., 2004), and critical values for each indicator. The relationships between indicators and soil functions indicate

Weighting factor for soil indicators and setting up an index for evaluation quality of salt-affected soils

\section{Weighting factor}

There are some ways to assess a relative weighting to a soil property value and then set up index for evaluating quality of salt-affected soils. Two of these ways are briefly described below:

1.1) Weightingfactor by Lal (1994) and Shukla et al. (2004): some additional values and weighting factors are listed in Table 3. These values are ranked between 1 (no limitations) where soil quality is excellent, to 5 (extreme limitations) where soil quality is a constant to agronomic production and other functions. Similarly soil properties can be ranked between 1 and 5 depending on the severity of limitations.

1.2) Weighing factor by Asadi et al. (2008): the ranking is assigned a value of 0 or 1 depending on the severity of limitation. As an example of less is better, the ranking is 1 if the $\mathrm{EC}$ value is $<4 \mathrm{dS} / \mathrm{m}$, and 0 to $>4 \mathrm{dS} / \mathrm{m}$. As an example of more is better, the ranking is 1 if SOC is $>$ $2 \%$ and 0 if it is $<2 \%$. Similarly, an example of an optimum is better; the ranking is 1 if the $\mathrm{pH}$ is $6.6-7.3$, and 0 if it is less or more than this value.

\section{Setting up index}

There are many indices that were established by many authors. Although these indices are general for assessing soil quality in general status, some of these are flexible and can be used for this purpose in special cases such as the instant case. Two of these indices are:

1) $\quad$ Total $\mathrm{SQI}=\Sigma$ individual soil property index values (for the measured values Env. Biodiv. Soil Security Vol.1 (2017) 
only).......Eq.3a (Amacher et al., 2007), based on this index, if all 23 soil properties in Table 2 are measured and meet the threshold values depending on the relationship (more, less or optimum), the maximum value for Total SQI will be 23. Then, soil quality is expressed as a percentage of the maximum of 23:

$(\mathrm{SQI} \%=($ total SQI $/$ maximum possible total SQI for properties measured)x $100) \ldots \ldots \ldots \ldots \ldots \ldots \ldots \ldots . . . . . . . . .3 b$

The SQI ranges between $0-100$. In this index, only the measured prosperities contribute to the index calculation because the missing values for any not measured indicator can affect the SQI. This index expresses the degree of soil quality as a percentage of the measured indicators. Thus, soil quality can be excellent $(\mathrm{SQI}=20-23=100$ $86.96 \%)$, very good $(\mathrm{SQI}=17-20=73.91-86.96$ $\%), \operatorname{good}($ Total SQI $=15-17=65.22-73.91 \%$ ), moderate $(\mathrm{SQI}=11-15=47.83-65.22 \%)$ low $(\mathrm{SQI}>11>47.83 \%)$.

2)

$$
\left.\mathbf{S Q} \mathbf{I}=\left[\frac{\sum_{i-1}^{n} S i}{n}\right) X 10\right]
$$

Eq. 4

(Andrews et al., 2003 and Andrews et al., 2004): where the $(\mathrm{Si})$ is the score of soil property and (n) is the number of measured properties. This index similar to the previous index, but the difference is that this index is multiple by 10 , then the resulted SQI value will range between 0 (low performance of soil functions) - 10 (high performance).

Subsequently after measuring the soil properties in the area ofknownorassumedsalinity, the MDS should be set and the quality of this soil should be assessed based on the previous steps. Indeed, all of this effort is to enhance the productivity and sustainability of this soil.

Case study on physo-chemical parameters in some salt affected soil in Egypt

To assess soil quality in salt affected soils some parameters were selected from the available data in some locations (12

Env. Biodiv. Soil Security Vol.1 (2017) locations). Some of this data are quoted from Abbas et al., (2004) and El_Gannam (2012). Other data is personal unpublished data for other locations in North delta; Egypt. Generally, all sites are located in North or East Nile delta (Kafr_ELshiekh and Sharkia governrates).

The assessment steps were as follows:

1- Selecting indicators: The indicators which will form a minimum data set for assessing the quality of soils are selected according to the suggested ones in Table 2. With notice that only some indicators in that table will not be used in this case study because of data availability in the mentioned locations. The selecting indicators are presented in Table 4. The most available data are chemical and physical soil properties not biological because of shortage of these biological data in Egypt generally not only in the selected locations.

2- Transforming indicators into scores: If the indicator meets the threshold value in Table 2 it will take 1 and 0 otherwise.

3- Integration of resulted scores to indices: The transformed data will be used in the previous equations (i.e. 3 and 4); the results in Eq. 3 will be modified based on the total used indicators to get the total percentage based of their numbers.

4- Conducting the category of soil quality based on two used indices: (i.e. low, moderate, good, very good, excellent or low, moderate, high performance based on Eq. 3 and 4 respectively).

5- Compare between the results from the two indices: According to the resulted data in Table 4; all studied locations have low or moderate quality of its soil. In our point of view; the situation will not differ so much if the biological data are available because the existing data are considering as an indicator for the soil properties generally; of course, of these data are available and minimum data set is completed for the assessing it will be better. Additionally; no difference between the two used indices, which is predicted that any of those indices can be used in the future studies. 


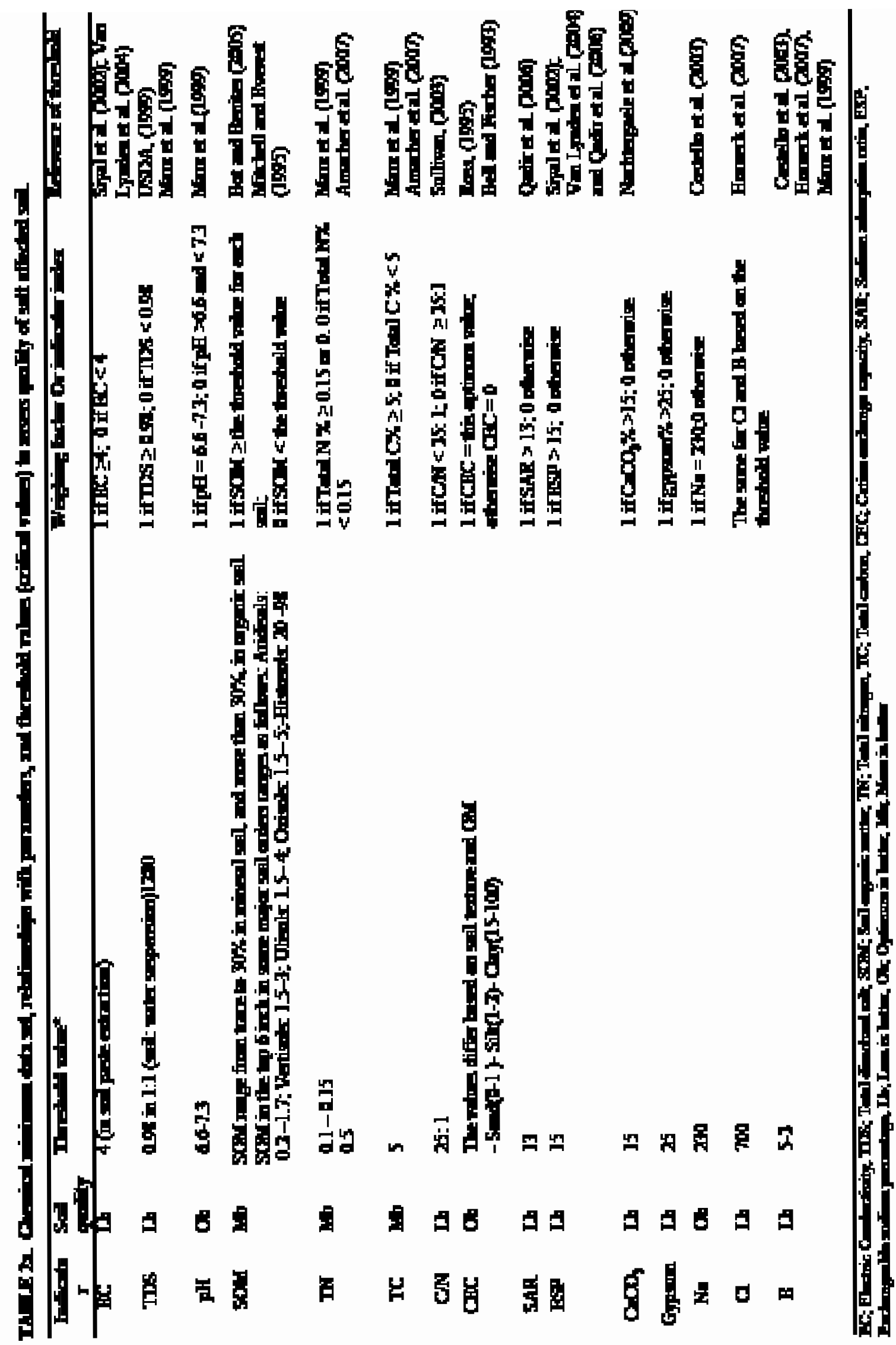




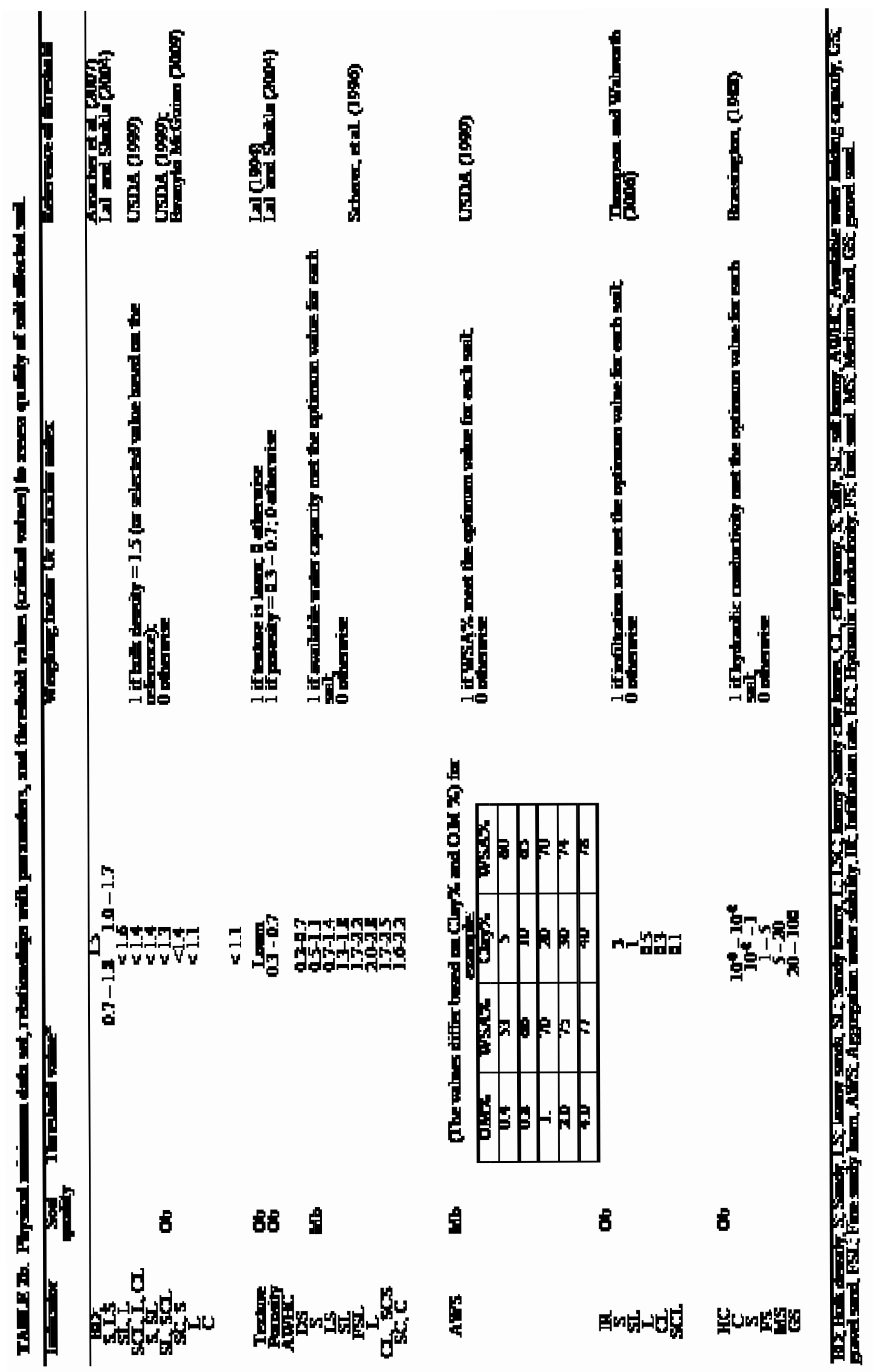

Env. Biodiv. Soil Security Vol.1 (2017) 

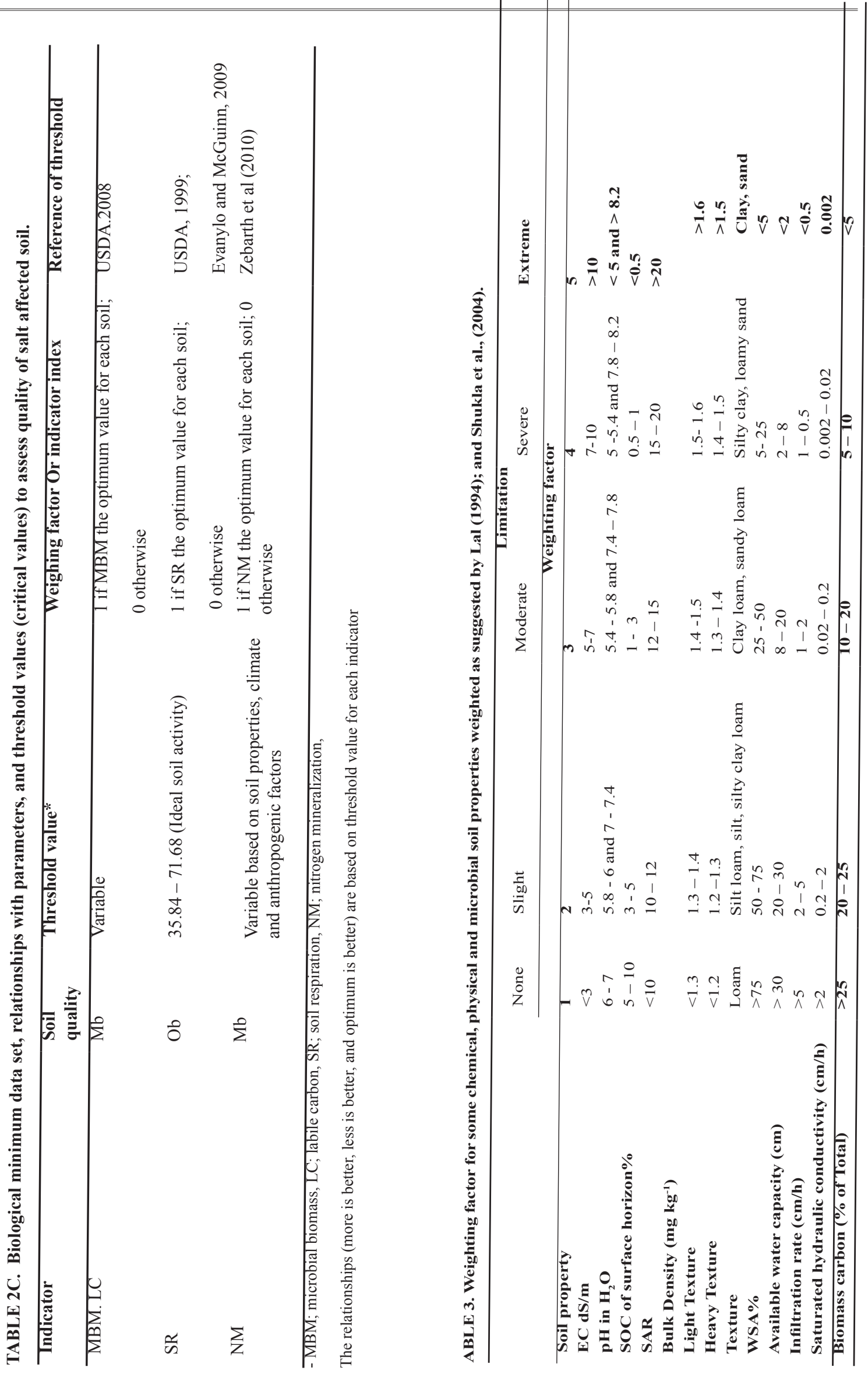

Env. Biodiv. Soil Security Vol.1 (2017) 


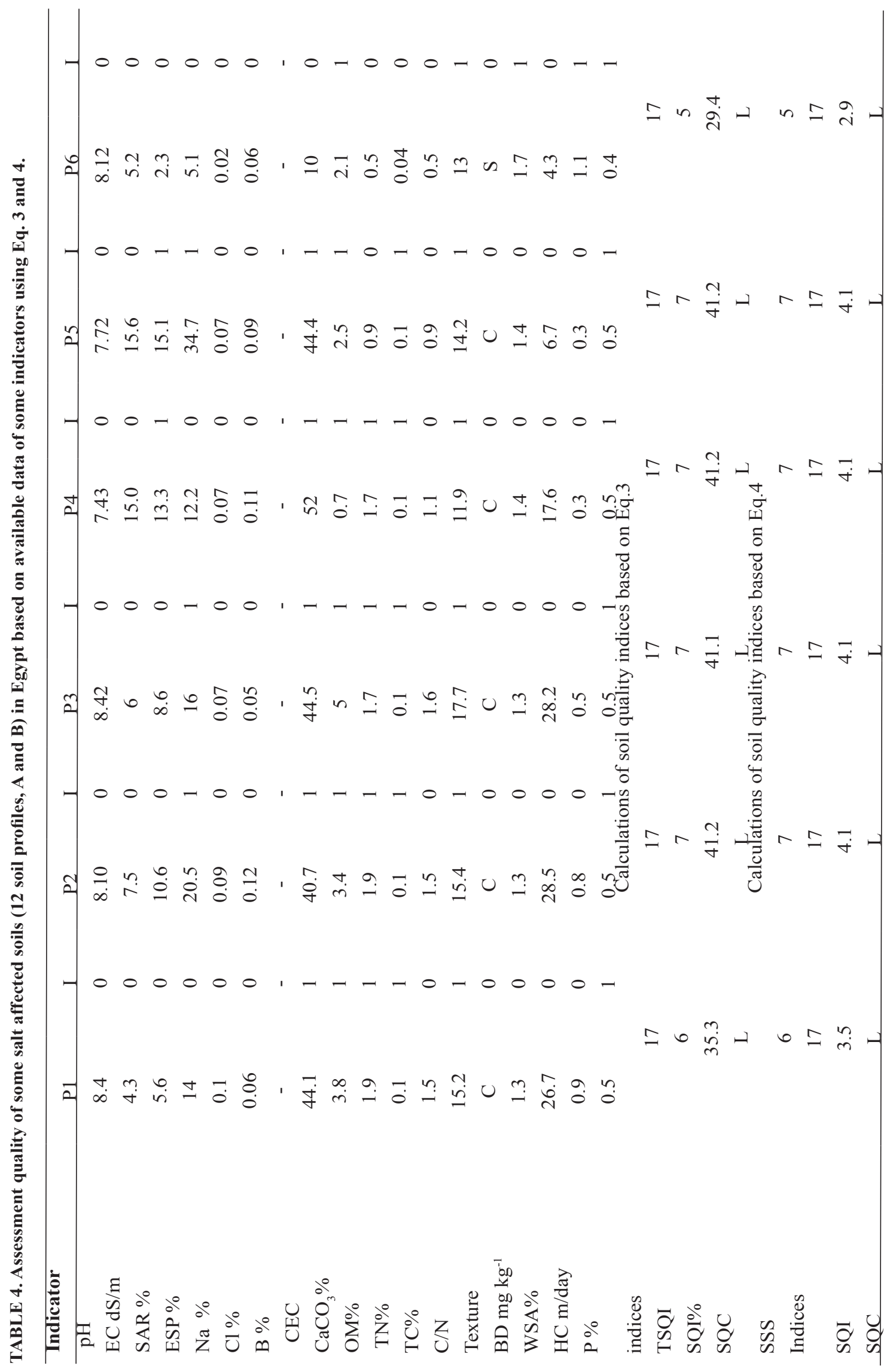

Env. Biodiv. Soil Security Vol.1 (2017) 


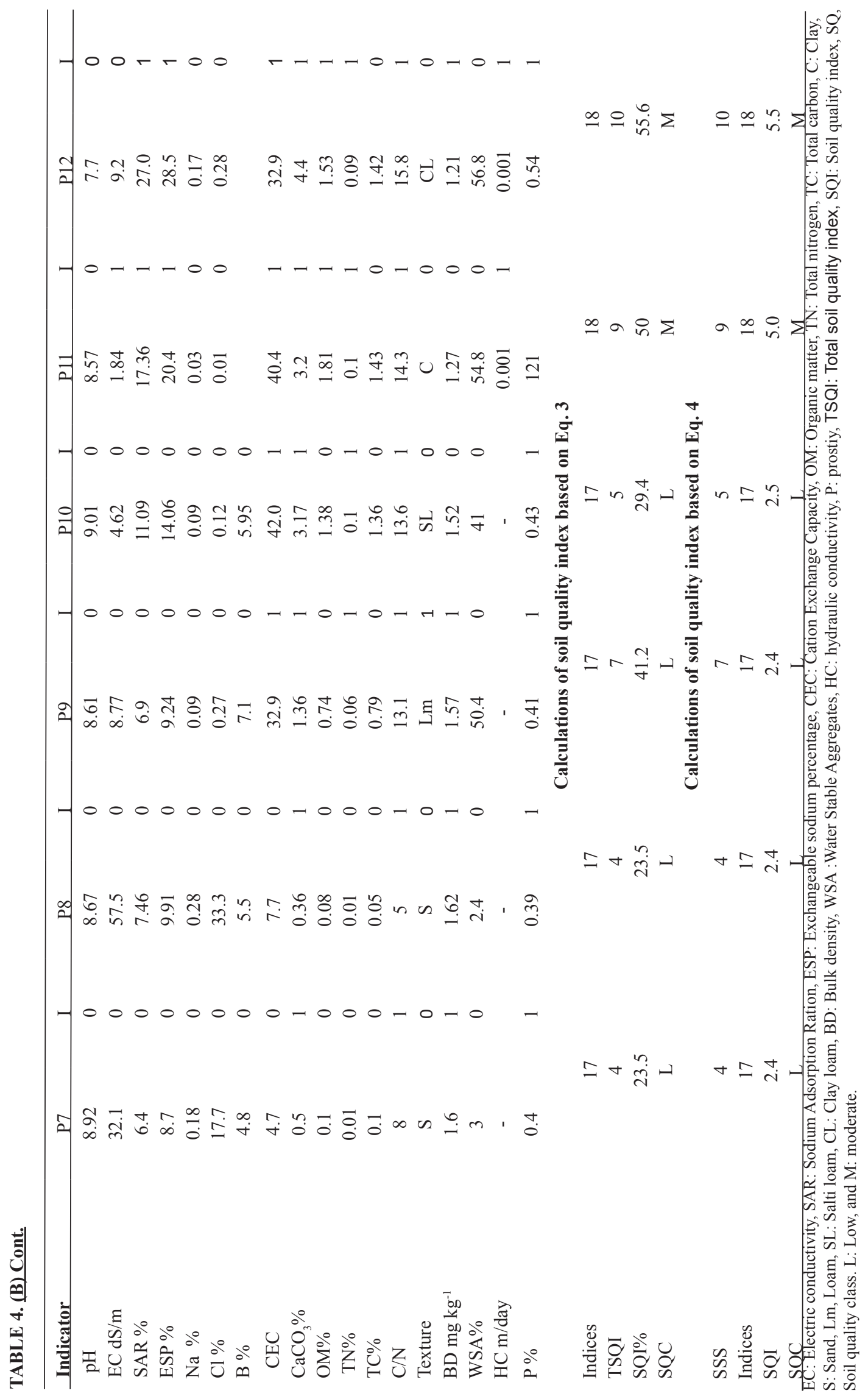

Env. Biodiv. Soil Security Vol.1 (2017) 


\section{Conclusion}

There is an urgent need to monitor and assess soil quality especially in salt-affected soils because these soils can be used to increase food and feed productivity; enhance environmental quality and increase carbon sequestration. Therefore, through this paper it can be selected appropriate indicators for establishing suitable MDS to assess and enhance the quality of salt-affected soils. This study suggested MDS composite from basic soil properties and others related to salinity. In addition, thresholds values for the selected indicators were established for this purpose based on published studies. Although there is no universal index for assessing soil quality under different conditions, some flexible and valuable indices can be used in this matter. Of these indices, two were selected to assess the quality of salt-affected soils. The calculations of these indices are flexible because they depend only on soil quality indicators which were measured for the assessment. This leads to accurate results because of exclusion the missing indicators. These indices also can give a complete picture, about soil conditions and its functioning, to farmers and land managers to improve soil quality. Based on the case study the quality of soils in some assessed salt affected ones is low or moderate. This indication should be taken into consideration to manage these soils for improving productivity and enhancing sustainability. Ultimately, more studied are required for assessing soil quality especially in salt-affected and degraded soils to establish universe index that can be used in any conditions.

\section{References}

Abbas, H.H., Noufal, E.H.A, Abd-El Aziz SM,Saeid HS. (2004) Effect of gypsum application method on improving chemical and physical properties of sodic soils. Workshop on "Agricultural Development in The Arab Nation, Obstacles \& Solutions" Jan. 2022, 2004 - Assiut - Egypt. 320-334.

Abdelfattah MA, Shahid SA,OthmanYR. (2009) Soil Salinity Mapping Model Developed Using RS and GIS - A Case Study from Abu Dhabi, United Arab Emirates. European Journal of Scientific Research, 26 (3), 342-351.

Env. Biodiv. Soil Security Vol.1 (2017)
Amacher MC, O’Neil KP, PerryCH. (2007) Soil vital signs: A new Soil Quality Index (SQI) for assessing forest soil health. Res. Pap. RMRS-RP-65WWW. Fort Collins, CO: U.S. Department of Agriculture, Forest Service, Rocky Mountain Research Station.

Andrews SS, Caroll CR. (2001) Designing A Soil Quality Assessment Tool For Sustainable Agroecosystem Management. Ecological Applications, 11 (6), 1573-1585.

Andrews SS, Flora CB, Mitchell JP, Karlen DL.(2003) Growers' Perceptions and Acceptance of Soil Quality Indices. Geoderma, 114, 187-213.

Andrews SS, Karlen DL, Cambardella CA. (2004) The Soil Management Assessment Framework: A Quantitative Soil Quality Evaluation Method. Soil Sci. Soc. Am. J., 68, 1945-1962.

Arshad MA, Martin S. (2002) Identifying critical limits for soil quality indicators in agro-ecosystems. Agriculture, Ecosystems and Environment, 88, 153-160.

Asadi SS, Azeem S, Prasad AVS, Reddy MA. (2008). Analysis and mapping of soil quality in khandaleru catchment area using remote sensing and GIS. Current Science, 95, 3- 391-396.

Baldwin KR. (2006) Soil Quality Considerations for Organic Farmers.North Carolina Cooperative Extension Service.College of Agriculture \& Life Science-Academics Research Extensions.

Bell MA., Fischer RA. (1993) Guide to soil measurements for agronomic and physiological research in small grain cereals. Wheat Special Report No. 18.Mexico, D.F.; Cimmyt.

Bohn HL, McNeall BL, O'Connor GA. (2001) Salt affected soils. In: Soil Chemistry. 3rd ed. John Wiley \& Sons Inc.

Bot A, Benites J. (2005) The importance of soil organic matter.Key to drought-resistant soil and sustained food and production.FAO Soils Bulletin $\mathbf{8 0}$.

Braimoh AK,Vlek PLG.( 2008) Land Use and Soil Resources. Springer Science+Business Media B.V. Library of Congress.

Brassington R. (1988) Field Hydrogeology.Geological Society of London Handbook Series.Open University Press.

Cassman KG. (1999) Ecological intensification of cereal production systems: Yield potential, soil quality, and precision agriculture. Proc. Natl. Acad. 
Sci. USA, 96, 5952-5959.

Cilenti A, Provenzano MR, Senesi N. (2005) Characterization of dissolved organic matter from saline soils by fluorescence spectroscopy. Environ Chem Lett, 3, 53-56.

Costello LR, Perry EJ, Metheny NP, Henry JM, GeiselPM. (2003) Abiotic Disorders of Landscape Plants: A Diagnostic Guide.University of California. Agriculture and Natural resources. Publication 3420.

Doran JW, Parkin TP. (1994) Defining and assessing soil quality. In: Doran JW, Coleman DC, Bezdicek DF, Stewart BA (Eds.), Defining Soil Quality for a Sustainable Environment, Madison, WI. Soil Sci. Soc. Am., 35, 3-21(special publication).

Dumanski. (1997)Criteria and indicators for land quality and sustainable land management. ITC Journal, 3 /4.

El-Gannam MKA. (2012)Influence of water level fluctuation in the ends of drains and water canal in the ends of drains and water canals of the properties of soil and ground water in North Nile Delta. Thesis submitted in partial fulfillment of the requirements of the degree of Master of Science. Soil Science Department, Faculty of Agriculture, Kafr-Elsheikh University.

El-Swaif SA. (2000) Soil and Water Salinity. In: Silva, J. A and R. Uchida, eds. Plant Nutrient Management in Hawaii's Soils, Approaches for Tropical and Subtropical Agriculture. College of Tropical Agriculture and Human Resources, University of Hawaii at Manoa.

Evanylo G, McGuinn R. (2009) Agricultural Management Practices and Soil Quality: Measuring, assessing, and comparing laboratory and field test kit indicators of soil quality attributes. Virginia Polytechnic Institute and State University. Publication 452-400.

Eynard A, Lal R, Wiebe K. (2005) Crop Response in Salt-Affected Soils. Journal of Sustainable Agriculture, 27, 15 - 50.

Farifteh J, Meer F, Atzberger C, Carranza EJM. (2007) Quantitative analysis of salt-affected soil reflectance spectra:A comparison of two adaptive methods (PLSR and ANN). Remote Sensing of Environment, 110, 59-78.

Farifteh J, Meer F, Meijde M, Atzberger C. (2008) Spectral characteristics of salt-affected soils: A laboratory experiment. Geoderma, 145, 196-206.
Glover JD, Reganold JP, Andrews P K. (2000) Systematic Method for Rating Soil Quality of Conventional, Organic, and Integrated Apple Orchards in Washington State. Agriculture, Ecosystem and Environment, 80, 29-45.

Halvorson JJ, Smith JL, Papendick R I. (1996) Integration of multiple soil parameters to evaluate soil quality: A field example. Biol. Fertil. Soils, 21, 207-214.

Herrick JE. (2000) Soil quality: an indicator of sustainable land management? Applied Soil Ecology, 15, 75-83.

Horneck DA, Ellsworth JW, Hopkins BG, Sullivan DM, Stevens RG. (2007) Managing salt-affected soil for crop production.A Pacific Northwest Extension publication.Oregon State University - University of Idaho - Washington State University.

Karlen DL,Stott DE (1994) A framework for evaluating physical and che mical indicators of soil quality. In: Defining Soil Quality For A Sustainable Environment, 53-72, Doran JW, Coleman DC, Bezdicek DF, Stewart BA (eds.). SSSA Press, Madison.

Karlen DL, Mausbach JJ, Doran JW, Cline RG, Harris RF, Schuman GE. (1997) Soil Quality: A Concept, Definition, and Framework for Evaluation. Soil Sci. Soc. Am. J., 61, 4-10.

Lakhdar A, Scelza R, Scotti R, Rao MA, Jedidi N, Gianfreda L, Abdelly C. (2010) The effect of compost and sewage sludge on soil biologic activities in salt affected soil, R.C. Suelo Nutr. Veg. 10(1), $40-47$.

Lal R. (1994) Methods and Guidelines for Assessing Sustainable Use of Soil and Water Resources in the Tropics. Soil Management Support Services, USDA- Soil Conservation Services and U.S. Agancy for International Development. SMSS Technical Monograph No. 21.

Lal R. (2004) Carbon sequestration in dryland ecosystems, Environmental Management, 33 (4), 528-544.

Lal R. (2008)Carbon sequestration. Philosophical Transaction Of The Royal Society B. 363, 815-830.

Lal R, Shukla, MK. (2004) Principles Of Soil Physics, Marcel Dekker, Inc. 691pp.

Lal R, Kimble JM, Follett RF, Stewart BA. (1997) Soil Processes And The Carbon Cycle. CRC press. 
Larson WE, Pierce FJ. (1994) The dynamics of soil quality as a measure of sustainable management. In: Defining of Soil Quality for a Sustainable Environment, The Soil Science Society of America, Inc.

Lee C, Wu M, Asio VB, Chen Z. (2006) ZTaiwan. Soil Science, 171 (3), 210-222.

Leirós MC, Trasar-Cepeda C, García-Fernández F,Gil-Sotres F.(1999) Defining TheValidity Of A Biochemical Index Of Soil Quality. Biol Fertil Soils, 30, 140-146.

Li X, Rengel Z, Mapfumo E, Singh B. (2007) Increase in $\mathrm{pH}$ stimulates mineralization of 'native' organic carbon and nitrogen in naturally salt-affected sandy soils. Plant Soil. 290, 269-282.

Marcum KB. 2006. Use of saline and non-potable water in the turfgrass industry: Constrains and developments. Agriculture Water Management,80, 132-146.

Marx ES, Hart J,Stevens RG. (1999) Soil Test Interpretation Guide.EC 1478.Oregon State University Extension Service.

Mashali AM. (1999) Land degradation with focus on salinization and its management in Africa. In: Integrated Soil Management For Sustainable Agriculture And Food Security In Southern And East Africa, Nabhan H, Mashali AM, Mermut AR. Proceedings of the expert consultation. Harare, Zimbabwe 8-12 December 1997. FAO.

McCauley A, Jones C. (2005) Salinity \&sodicity management. A self-study course from the MSU Extension Service Continuing Education Series. Montana State University.

Mitchell CC, Everest JW. (1995) Interpreting soil organic matter tests.Soil Testing \& Plant Analysis. Southern Regional Fact sheet.SERA-IEG-6*1. Dept. Agronomy \& Soils, Auburn University, AL 36849

Moebius BN, Van Es HM, Schindelbeck RR, Idowu OJ, Clune DJ, Thies JE. (2007) Evaluation of laboratory-measured soil properties as indicators of soil physical quality. Soil Science, 172, No. 11.

Nachtergaele F, van Velthuizen H,Verelst L. (2009) Harmonized World Soil Database Version 1.1.FAO, IIASA, ISRIC, ISSCAS, and JRC.

Norfleet ML, Ditzler CA, Puckett WE, Grossman RB, Shaw JN. (2003) Soil quality and its relationship to pedology.Soil Science, 168 (3).

Env. Biodiv. Soil Security Vol.1 (2017)
Nortcliff S. (2002) Standardisation of soil quality attributes. Agriculture, Ecosystems and Environment, 88, 161-168.

Odeh IOA, Onus A. (2008) Spatial Analysis of Soil Salinity and Soil Structural Stability in a Semiarid Region of New South Wales, Australia. Environmental Management, 42, 265-278.

Oostrum A. (2004) Threshold values and estimation methods for selected types of degradation. In: Lynden GWJ, Mantel S, van Oostrum A. Guiding Principles For The Quantitative Assessment Of Soil Degradation- With A Focus On Salinization, Nutrient Decline And Soil Pollution. FAO/ISRIC.

Qadir M, Noble AD, Schubert S, Thomas RT, Arslan A. 2006.Sodicity-induced land degradation and its sustainable management: Problems and prospects. Land Degradation \& Development, 17, 661 - 676.

Raman S. (2006) Agriculture Sustainability: Principles, Proceskses, And Prospects. Food Products Press. pp 474.

Rengasamy P. (2010) Soil processes affecting crop production in salt-affected soils. Functional Plant Biology, 37, 613-620

Rietz DN, Haynes RJ. (2003) Effects of irrigationinduced salinity and sodicity on soil microbial activity. Soil Biology \& Biochemistry, 35, 845-854.

Ross DS. (1995) Recommended Methods for Determining Soil Cation Exchange Capacity. In: Recommended Soil Testing Procedures for The Northeastern United States. 2nd Edition. Northeastern Regional Publication No. 493. 92pp.

Sa'nchez-Marano'n M, Soriano M, Delgado G,Delgado R. (2002) Soil Quality in Mediterranean Mountain Environments: Effects of Land Use Change. Soil Sci. Soc. Am. J, 66, 948-958

Sanchez PA, Palm CA, Buol SW. (2003) Fertility Capability Soil Classification: A Tool to Help Assess Soil Quality in the Tropics. Geoderma, 114, $157-185$.

Sant'anna SAC, Saviozzi A, Levi-Minzi R, Cardelli R, Riffaldi R. (2001) A Comparison of Soil Quality in Adjacent Cultivated, Forest and Native Grassland Soils. Plant and Soil, 233, 251-259.

Scherer T F, Seelig B, Franzen D. (1996) Soil, Water and Plant Characteristics Important to Irrigation. North Dakota State University and U.S. Department of Agriculture cooperating. EB-66. 
Schindelbeck R R, van EsH M, Abawi G S, Wolfe DW, Whitlowe TL, Guginob B K, Idowua OJ, MoebiusClunea BN. (2008) Comprehensive assessment of soil quality for landscape and urban management. Landscape and Urban Planning, 88, 73-80.

Seker, C., Özaytekin, H.H., Negi s, H., r Gümü s, L., Dedeoglu, M., Atmaca, E., Karaca., U (2017). Identification of regional soil quality factors and indicators: a case study on an alluvial plain (central Turkey). Solid Earth, 8, 583-595. doi:10.5194/se8-583-2017.

Shukla M K, Lal R, Ebinger M. (2004) Soil Quality Indicators for the North Appalachian Experimental Watersheds in Coshocton Ohio. Soil Science, 169 (3), 195-205.

Shukla M K, Lal R, Ebinger M. (2006) Determining soil quality indicators by factor analysis. Soil \& Tillage Research, 87, 194-204.

Siyal AA, Siyal A G, Abro ZA. (2002) Salt affected soils their identification and reclamation. Pakistan Journal of Applied Sciences, 2(5), 537-540.

Sposito G, Zabel A. (2003) The assessment of soil quality. Geoderma, 114, 143- 144.

Sullivan p. (2003) Overview of cover crops and green manures.Fundamentals of sustainable agriculture. National Center for Appropriate Technology.

Thompson TL, Walworth JL. (2006) Salinity management and soil amendments for southwestern pecan orchards.The University of ArizonaCooperative Extension.College of Agriculture and Life Sciences. AZ1411.

Tóth G, Stolbovoy V, Montanarella, L. (2007) Soil Quality and Sustainability Evaluation - An Integrated Approach to Support Soil-Related Policies of The European Union. European Commission- Directorate-General Joint Research Centre-Institute for Environment and Sustainability.

Tóth G, Montanarella L, Rusco E. (2008) Threats to Soil Quality in Europe.European Commission.Joint Research Centre- Institute for Environment and Sustainability.

United States Salinity Laboratory Staff. (1954) Diagnosis and improvement of saline and alkali soils, Handbook 60, United States Department of Agriculture (USDA), Washington, DC.

USDA. (1999) Soil Quality - Test Kit Guide, United States - Department of Agriculture.

USDA. (2001) Guidelines for Soil Quality Assessment in Conservation Planning, United States Department of Agriculture - Natural Resources Conservation Service- Soil Quality Institute.

USDA (2008) Soil Quality Physical Indicators: Selecting Dynamic Soil Properties to Assess Soil Function, Soil Quality Technical Note No. 10. Natural Resources Conservation Service. Soil Quality National Technology Development Team Soil Quality Technical Note No. 10 was prepared by Dr. Holli Kuykendall, Soil Quality National Technology Development Team, East National Technology Support Center, Natural Resources Conservation Service (NRCS), Greensboro, NC.

Van Lynden G WJ, Mantel S, Van Oostrum A. (2004) Guiding Principles for the quantitative assessment of soil degradation- with focus on salinization, nutrient decline and soil pollution, International Soil Reference and Information Center. FAO.

Wander MM, Bollero GA. (1999) Soil quality assessment of tillage impacts in illinois. Soil Sci. Soc. Am. J,63, 961-971.

Wander MM, Drinkwater LE. (2000) Fostering soil stewardship through soil quality assessment. Applied Soil Ecology, 15, 61-73.

Wang Z, Chang AC, Wu L, Crowley D. (2003) Assessing the soil quality of long-term reclaimed wastewater- irrigated cropland. Geoderma,114, 261-278.

Wong VNL, Greeno RSB, Murphy BW, Dalal D, Mann S. (2004) Carbon dynamic in salt- affected soils. In: Roach, I.C. Ed. 2004. Regolith 2004. CRC LEME, $407-410$.

Wong V N L, Greeno R S B, Murphy B W, Dalal R, Mann S, Farquhar G. (2006) The effects of salinity and sodicity on soil organic carbon stocks and fluxes: An overview. Regolith 2006- Consolidation and Dispersion.

Zalidis G, Stamatiadis S, Takavakoglou V, Eskridge K, Misopolinos N. (2002) Impacts of agricultural practices on soil and water quality in the Mediterranean region and proposed assessment methodology. Agriculture, Ecosystems and Environment, 88, 137-146.

Zebarth B J, Burton D L, Sharifi M, Cooper J, GrantC A, Drury CF. (2010) Relationships among mineralizable soil nitrogen, soil properties, and climatic indices. Soil Sci. Soc. Am. J.,74 (4), 1218-1227.

Zhengchao Z, Xiaoyan Z, Zhuoting G. (2015) Changes in soil organic carbon and nitrogen after 26 years of farmland management on the Loess Plateau of

Env. Biodiv. Soil Security Vol.1 (2017) 
China. Arid Land, 7(6), 806-813.

Zornoza R, Mataix-Solera J, Guerrero C, Arcenegui V, García-Orenes F, Mataix-Beneyto J, Morugán A. 2007. Evaluation of Soil Quality Using Multiple Lineal Regression Based on Physical, Chemical and Biochemical Properties. Science Of The Total Environment, 378, 233-237.

Zornoza R, Mataix-Solera J, Guerrero C, Arcenegui V, Mataix-Beneyto J, Gomez I. (2008) Validating the effectiveness and sensitivity of two soil quality indices based on natural forest soils under Mediterranean conditions. Soil Biology \& Biochemistry, 40, 2079-2087.

Zvomuya F, Janzen HH, Larney FJ, Olson B M. (2008) A long-term field bioassay of soil quality indicators in a semiarid environment. Soil Sci. Soc. Am. J., 72 (3).

(Received 13/5/2017; Accepted 12/ 6/ 2017) 